\title{
Identification of pigment profiles and antioxidant activity of Rhizophora mucronata mangrove leaves origin Lembeh, North Sulawesi, Indonesia
}

\author{
ANTONIUS PETRUS RUMENGAN ${ }^{1, \vartheta}$, ELVI SISKA MANDIANGAN ${ }^{2}$, WENDY ALEXANDER TANOD ${ }^{3}$, \\ DARUS SAADAH JOHANIS PARANSA ${ }^{1}$, CAROLUS PAULUS PARUNTU ${ }^{1}$, DESY MARIA HELENA MANTIRI ${ }^{1}$ \\ ${ }^{1}$ Department of Marine Science, Faculty of Fisheries and Marine Science, Universitas Sam Ratulangi. Jl. Kampus UNSRAT Bahu, Manado 95115, North \\ Sulawesi, Indonesia. Tel./fax.: +62-852-4027-3030, ’email: antonius_rumengan@unsrat.ac.id \\ ${ }^{2}$ Research and Development Agency of North Sulawesi Province. Jl. 17 Agustus, Bumi Beringin, Wenang, Manado 95113, North Sulawesi, Indonesia \\ ${ }^{3}$ Department of Fisheries and Marine, Politeknik Negeri Nusa Utara. Jl. Kesehatan, Mahena, Tahuna, Kepulauan Sangihe 95812, North Sulawesi, \\ Indonesia
}

Manuscript received: 23 May 2021. Revision accepted: 21 June 2021

\begin{abstract}
Rumengan AP, Mandiangan ES, Tanod WA, Paransa DSJ, Paruntu CP, Mantiri DMH. 2021. Identification of pigment profiles and antioxidant activity of Rhizophora mucronata mangrove leaves origin Lembeh, North Sulawesi, Indonesia. Biodiversitas 22: 2805-2816. Mangroves plants contain unique pigments which can serve both nutraceutical and pharmaceutical purpose. Therefore, this preliminary study aims to identify the pigment profiles of Rhizophora mucronata mangrove leaves (HPLC method) and to computationally evaluate the antioxidant mechanism of the pigments (PASS and STITCH analysis). Furthermore, it evaluated the antioxidant capacity of $R$. mucronata leaves extracts (DPPH method), and the pigment profiles detected using HPLC were chlorophyll a (68.61\%), chlorophyll b (27.69\%), lutein (29.94\%), beta-carotene (14.05\%), pheophytin a (8.72), violaxanthin (5.19\%), and neoxanthin (3.65\%). Beta-carotene, lutein, neoxanthin, and violaxanthin were predicted to have potential as antioxidants properties using PASS analysis. While neoxanthin and violaxanthin were predicted as free radical scavengers, beta-carotene was an Nrf-2 stimulant. The STITCH analysis showed that the pigments contained in the leaves interacted synergistically by activating as antioxidant enzymes and inhibiting the expression of oxidative stress proteins. The ethanol extract of $R$. mucronata leaves may be a potent antioxidant with an IC50 $20.99 \pm 0.33 \mu \mathrm{g} / \mathrm{mL}$. Therefore, the pigment contained in $R$. mucronata leaves is a potential source of antioxidants.
\end{abstract}

Keywords: Beta-carotene, chlorophyll, lutein, neoxanthin, violaxanthin

\section{INTRODUCTION}

Mangrove plants live in low tide areas, and they play a critical role in the coastal ecosystem by supporting fisheries, tourism, and a genetic reservoir (Liu 2012). It functions as a protector of the coastline, preventing seawater abrasion, the habitat of various aquatic biota, and acts best carbon storage ecosystem (Kepel et al. 2017; Rumengan et al. 2018; Saptiani et al. 2018; Tidore et al 2018). Furthermore, coastal communities have also used mangroves for house construction, charcoal making materials (Dahdouh-Guebas et al. 2000), functional foodstuffs (Jariyah et al. 2014; Kardiman et al. 2017; Analuddin et al. 2019), textile dyes (Pringgenies et al. 2017), and traditional medicine (Revathi et al. 2014; Rout and Basak 2014; Alhaddad et al. 2019; Andriani et al. 2020). These plants have a self-defense mechanism because they live in areas with fluctuations in salinity and temperature (Dewanto et al. 2018). The mechanism designed consists of enzymatic and non-enzymatic antioxidants defense (Sarker et al. 2018a; Sarker and Oba 2018a; 2020a). Pigments in mangroves significantly affect photosynthetic reactions, stress avoidance, and defense mechanisms (Croft and Chen 2017).

Previous studies reported that leaves are the natural sources of pigments such as chlorophyll a, chlorophyll b, betacyanins, betaxanthins, betalains (Sarker et al. 2014; 2015a; 2015b; 2017). These are potential sources of carotenoids pigments such as beta-carotene, alphacarotene, xanthophylls including lutein, neoxanthin, zeaxanthin, and violaxanthin (Sarker and Oba 2021). In addition, leaves consist of other pigments such as phenolics and different groups of flavonoids, including flavonols, flavones, flavanones (Sarker and Oba 2019a; 2020b; 2020c), and they all exhibit high antioxidant capacity (Sarker et al. 2018b).

Previous studies also showed that mangroves contain unique pigments which may serve nutraceutical and pharmaceutical functions (Banerjee et al. 2017). One of the mangroves has the potential to use its pigment content such as Rhizophora mucronata (Pringgenies et al. 2018). Prabhu and Bhute (2015) reported that the brown pigment from the stem of $R$. mucronata was used as a textile dye. Furthermore, it was previously reported that the leaves contain chlorophyll and carotenoid pigments (Flores-deSantiago et al. 2016; Ridlo et al. 2017). However, no study has reported the complete profile of the pigments in the mangrove leaves of $R$. mucronata. The pigments can be used as a source of functional and natural food coloring (Mapari et al. 2005).

The mangrove Rhizophora mucronata showed medicinal potential for coastal communities. Meanwhile, the fruit, leaves, bark, and flowers of $R$. mucronata were used to treat various diseases, such as cognitive function 
(Suganthy and Pandima Devi 2016), diabetes (Bandaranayake 1998; Aljaghthmi et al. 2017), diarrhea (Puspitasar et al. 2012), hepatitis (Ravikumar and Gnanadesigan 2012), and inflammation (Rohini and Das 2009). The antioxidant capacity of the leaves obtained from India and Asia was widely reported (Imdadul et al. 2011). This is a preliminary study to identify the pigment profiles of Rhizophora mucronata mangrove leaves using the highperformance liquid chromatography method and to computationally evaluate the antioxidant mechanism of the pigments. Furthermore, it evaluated the antioxidant capacity of $R$. mucronata leaves extracts using the DPPH method.

\section{MATERIALS AND METHODS}

\section{Sampling and extraction}

Mangrove leaves sample (1000 g) was obtained from Lembeh Island, North Sulawesi, Indonesia. Rhizophora mucronata leaves were documented and put in a cool temperature container. They were collected in summer with hot sunny conditions (in July 2019) and were taken to the laboratory for extraction. The leaves were finely mashed to a powder, and the extraction was performed three times with ethanol pure grade (Merck) solvent. In addition, the $R$. mucronata leaves powder (100 g) was macerated using ethanol $(1: 3 \mathrm{w} / \mathrm{v})$ for 48 hours, with occasional shaking. The resultant maceration product was filtered through filter paper to separate the filtrate from the residue. Furthermore, the filtrate was evaporated (rotary vacuum evaporator Buchi R-300) at $40^{\circ} \mathrm{C}$ during $4-6$ hours to obtain a crude extract (Dewanto et al. 2018). According to Lichtenthaler (1987), the chlorophyll and carotenoid groups have a phytyl chain attached to the porphyrin ring system. The possession of the phytyl side chain, which is esterified to the ring carboxyl group, gives chlorophyll and carotenoids their lipid character. Therefore, ethanol is one of the polar solvents used to extract fat-soluble pigments from living plant tissues containing water. Figure 1 showed the location of mangrove leaves sampling.

\section{Identification of pigment profiles}

The identification of mangrove leaves pigments was conducted on a High-Performance Liquid Chromatography (HPLC-20AD-Shimadzu) with SPD-M20A photodiode array detector (PDA). The Pigment analysis was based on the method by Hegazi et al. (1998), and the Shimadzu UV1800 spectrophotometer was used in determining the wavelength. Meanwhile, the detection of mangrove leaves pigments was conducted by HPLC at $450 \mathrm{~nm}$ (carotenoids detection) and $660 \mathrm{~nm}$ (chlorophyll detection) respectively. The analytical column was a LiChroCART $250 \times 4$ mm I.D.

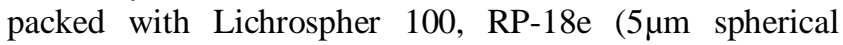
particles), and the precolumn was an ODS-hypersil (C18) with a diameter of $5 \mu \mathrm{m}, 20 \times 4 \mathrm{~mm}$.
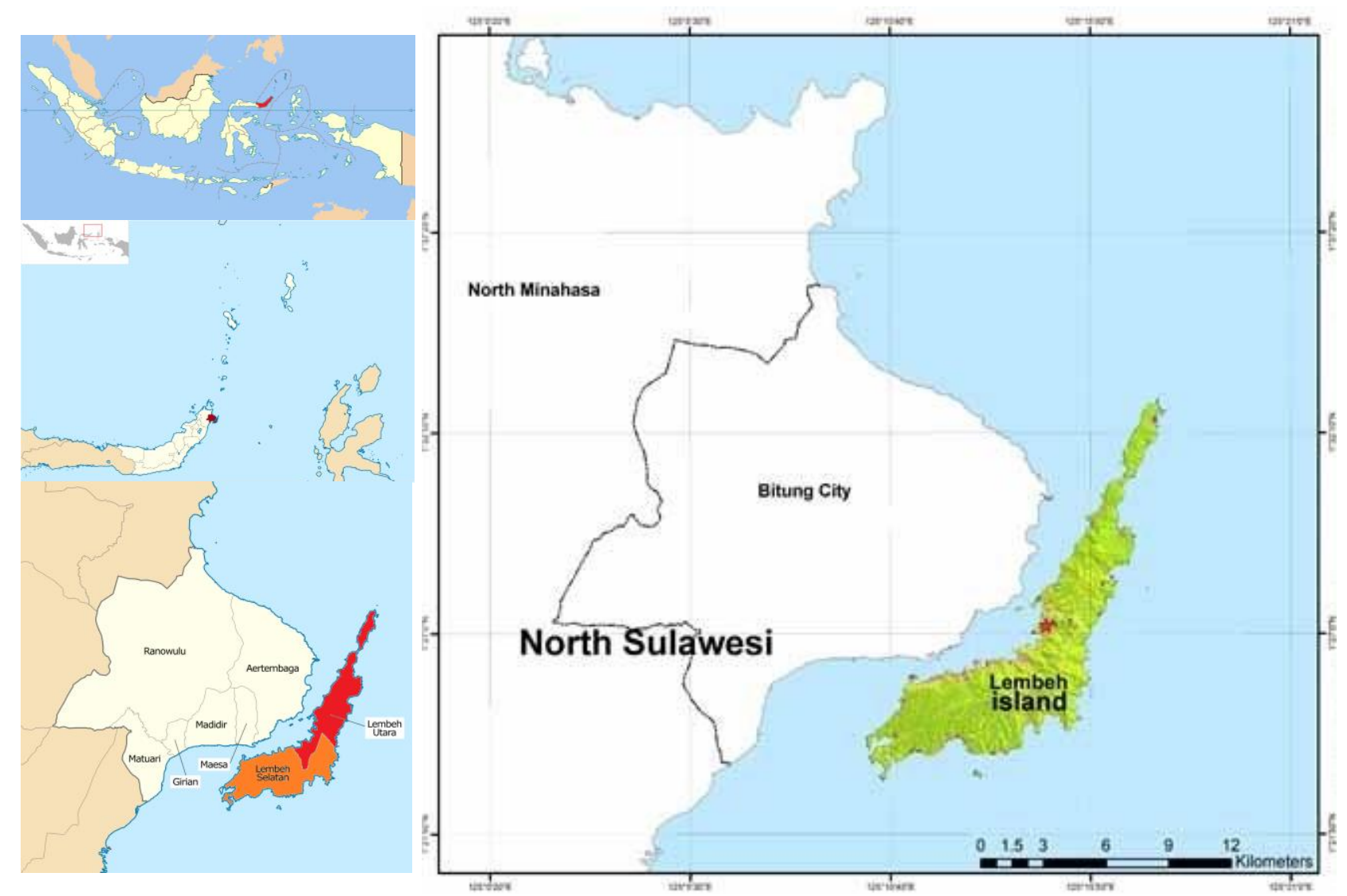

Figure 1. Location of Rhizophora mucronata mangrove leaves sampling in Lembeh Island, North Sulawesi, Indonesia $\left(1^{\circ} 27^{\prime} 8.78^{\prime \prime} \mathrm{N}\right.$ and $\left.125^{\circ} 14^{\prime} 41.90^{\prime \prime} \mathrm{E}\right)$ 
Dry pigment crude extract was dissolved in $5 \mathrm{~mL}$ acetone (Paransa et al. 2014) and filtered using a filter membrane $(0.2 \mu \mathrm{m})$, then $20 \mu \mathrm{L}$ was injected into HPLC. The pigment elution was conducted at a $1 \mathrm{~mL} / \mathrm{min}$ flow rate at $30{ }^{\circ} \mathrm{C}$ using a gradient elution system from a mixture of methanol, acetone, and ammonium acetate (1 M) solutions. Acetone was used in the pigment extraction because of its amphipathic nature of having a polar and a nonpolar end. Also, it has a significant partial negative and positive charge on the oxygen and carbonyl atom with two nonpolar alpha carbons. However, it is less polar than water and ethanol and can dissolve nonpolar substances. The nature of its small polarity allows it to dissolve polar substances and has fewer properties than water and ethanol. Therefore, acetone is an appropriate solvent, which allows more excellent resolution for detecting pigments using chromatography. It breaks chlorophyll lipid bonds to plant thylakoid structures and suspends pigments in solution (Henriques et al. 2007).

\section{Computational analysis}

The pigment detected with HPLC predicted biological activity-related antioxidants using the PASS (prediction of activity spectra for substances) analysis http://www.pharmaexpert.ru/passonline/index.ph. PASS is a tool used for predicting the biological activity of compounds (Riyadi et al. 2020). The predicted activity requires a structural formula in the form of canonical SMILE obtained from the National Center for Biotechnology Information https://pubchem.ncbi.nlm.nih.gov/. The pigments were analyzed for their interactions with the STITCH database (search tool for interactions of chemicals) http://stitch.embl.de/.

\section{Antioxidant assay}

Measurement of the antioxidant capacity of mangrove leaves was carried out using the DPPH method (Oke and Hamburger 2002), and the assays were conducted using 96 well plate microplates. The ethanol extract of Rhizophora mucronata leaves was prepared in series concentrations of $10,20,40,80 \mu \mathrm{g} / \mathrm{mL}$ in methanol solution (Merck). Then, $160 \mu \mathrm{L}$ of extract from each concentration series was fed into the microplate well. Furthermore, $40 \mu \mathrm{L}$ of $\mathrm{DPPH}$ (Merck) $0.76 \mathrm{mM}$ solution was added to each well that contained a sample. A comparison control used vitamin $\mathrm{C}$ with a concentration series of $4,6,8,10 \mu \mathrm{g} / \mathrm{mL}$. As a control sample, each series of dilutions $(160 \mu \mathrm{L})$ was added to the microplate well before adding $40 \mu \mathrm{L}$ of methanol. A negative control (without extract) was made by adding 160 $\mu \mathrm{L}$ methanol with $40 \mu \mathrm{L}$ DPPH, and $200 \mu \mathrm{L}$ methanol was blank. The microplate was incubated in a dark room at $25-$ $28^{\circ} \mathrm{C}$ for 30 minutes, and after that, the absorbance of each well was measured with the Multiskan GO Microplate Spectrophotometer (Thermo Scientific) at a wavelength of $517 \mathrm{~nm}$. The $\mathrm{IC}_{50}$ determination was measured from the inhibition percentage data in units of $\mu \mathrm{g} / \mathrm{mL}$, and a probit analysis was used to determine the $\mathrm{IC}_{50}$ value. The following equation was used to determine the percentage of DPPH inhibition:

$$
\% \text { Inhibition }=\frac{(C-D)-(A-B)}{(C-D)} \times 100 \%
$$

Where :
A: Sample absorbance
B: Absorbance control sample
C: Absorbance of negative control
D: Absorbance blank

\section{RESULTS AND DISCUSSION}

The dry extract of Rhizophora mucronata mangrove leaves was detected for pigment profiles by HPLC at a wavelength of 450 and $660 \mathrm{~nm}$, with a retention time of 20 to 40 minutes. Table 1 and Figure 2 showed the pigment profiles, and the chromatogram for the leaves extract.

Table 1 showed that the $R$. mucronata leaves extract detected seven pigments dominated by chlorophyll a $(68.61 \%)$ and chlorophyll b $(27.69 \%)$. Chlorophyll is a unique green pigment in almost every green part of plants, such as leaves (İnanç 2011). Chlorophyll a is a pigment with a chlorine ring, where magnesium is surrounded by four nitrogen atoms (Taiz et al. 2006). Meanwhile, in chlorophyll $\mathrm{b}$, the $-\mathrm{CHO}$ group replaces $-\mathrm{CH}_{3}$ on the $\mathrm{C} 7$ atom (Pareek et al. 2017). There is also chlorophyll $a$ and $b$ epimer at $11.69 \%$ and $5.19 \%$, and Limantara and Heriyanto (2012) stated that they always accompany the presence of chlorophyll. Chlorophyll $\mathrm{a}$ and $\mathrm{b}$ are common and dominant pigments in the leaves of green plants, such as mangroves (Liu 2012; Dou et al. 2018). Ridlo et al. (2017) reported $R$. mucronata leaves to contain chlorophyll and carotenoid pigments. Furthermore, Flores-de-Santiago et al. (2016) also reported that Rhizophora mangle leaves contain chlorophyll $\mathrm{a}$ and $\mathrm{b}$. Their levels depend on the season and physiological conditions of the mangroves. Bohn and Walczyk (2004) detected chlorophyll a and the epimer at the wavelength spectrum of 429, $664 \mathrm{~nm}$, while chlorophyll $\mathrm{b}$ and the epimer were discovered at 456, $648 \mathrm{~nm}$. Kusmita et al. (2015) detected chlorophyll-b at the wavelength spectrum of $456,596,645 \mathrm{~nm}$.

Lutein is a member of the xanthophyll and carotenoid family (Al-ali et al. 2020), and it has a yellowish-orange color, called macular pigment, which is not in abundance (Landrum and Bone 2001; Aruldass et al. 2018). Ngginak et al. (2017) reported detecting lutein on the wavelength spectrum of 417,443 , and $472 \mathrm{~nm}$, while Kurniawan et al. (2020) reported detected it at 447, 451, $472 \mathrm{~nm}$. Also, Sarker and Oba (2021) reported that leaves contain good macular pigment lutein. Previously, no study has detected lutein pigment in mangrove leaves. The detection was conducted using random sampling of old mangrove leaves that were yellowish in color. 
Table 1. Identification of pigment profiles from Rhizophora mucronata leaves with HPLC

\begin{tabular}{|c|c|c|c|c|c|c|}
\hline \multirow{2}{*}{$\begin{array}{l}\text { Wavelength } \\
\text { detection } \\
(\mathbf{n m})\end{array}$} & \multirow{2}{*}{$\begin{array}{c}\text { Retention } \\
\text { time } \\
(\text { min) }\end{array}$} & \multirow{2}{*}{$\begin{array}{c}\text { Area } \\
(\%)\end{array}$} & \multirow{2}{*}{$\begin{array}{c}\text { Wavelength } \\
\text { spectrum } \\
(\mathbf{n m})\end{array}$} & \multirow[t]{2}{*}{ Pigment profiles } & \multicolumn{2}{|c|}{$\begin{array}{l}\text { References } \\
\text { (Jeffrey et al. 1997; Zapata et al. 2000) }\end{array}$} \\
\hline & & & & & Retention time (min) & Wavelength spectrum (nm) \\
\hline 450 & 20.06 & 3.65 & $415,437,465$ & Neoxanthin & - & $415.1,438.5,467.1$ \\
\hline 450 & 21.72 & 5.19 & $417,442,470$ & Violaxanthin & 21.32 & $416,440,470$ \\
\hline 450 & 29.29 & 24.94 & $421,447,475$ & Lutein & 27.65 & $422,446,475$ \\
\hline 450 & 33.91 & 20.65 & $462,598,647$ & Chlorophyll b & 31.62 & $462,599,648$ \\
\hline 660 & & 7.04 & & & & \\
\hline 450 & 34.20 & 5.19 & $461,599,648$ & Chlorophyll b epimer & 31.87 & $462,599,650$ \\
\hline 450 & 35.53 & 11.30 & $430,617,663$ & Chlorophyll a & 33.15 & $431,617,662$ \\
\hline 660 & 35.53 & 57.31 & & & & \\
\hline 450 & 35.89 & 2.08 & $430,617,663$ & Chlorophyll a epimer & 33.48 & $430,615,664$ \\
\hline 660 & 35.89 & 9.61 & $430,616,663$ & & & \\
\hline 660 & 37.63 & 8.72 & $\begin{array}{l}409,505,535 \\
608,664\end{array}$ & Pheophytin a & - & $409.5,505.3,534.7,608.9,665.5$ \\
\hline 450 & 38.39 & 14.05 & 453,479 & Beta-carotene & 35.95 & $426,452,477$ \\
\hline
\end{tabular}

Beta-carotene is one of the red-yellow, orange or redorange carotenoids in natural plants that carry out photosynthesis (Kusbandari and Susanti 2017). It may be fat-soluble, insoluble in water, easily damaged, unstable at high temperatures, and precursor of vitamin A (Strobel et al. 2007). Furthermore, carotenoids including beta-carotene act as an antioxidant. Previous studies showed that they have strong DPPH and ABTS antioxidant activity in different amaranth species such as drought-tolerant amaranth (Sarker and Oba 2020d), A. gangeticus (Sarker et al. 2020a), A. hypochondriacus (Sarker and Oba 2020e), stem amaranth (Sarker et al. 2020b), A. blitum (Sarker and Oba 2020f), green amaranth (Sarker et al. 2020c), weedy amaranth (Sarker and Oba 2019b), and red amaranth (Sarker and Oba 2019c). Furthermore, carotenoids including beta-carotene protect the photosynthetic tissue through direct quenching of triplet chlorophyll. This prevents the generation of singlet oxygen from oxidative damage in abiotic stress like salinity and drought (Sarker and Oba 2020a). It also detoxifies various forms of reactive oxygen species (ROS) (Sarker and Oba 2018b; 2018c) through increasing beta-carotene concentration (Sarker and Oba 2018d; 2018e; 2019d). Beta-carotene is a pigment synthesized by plants (Bogacz-Radomska and Harasym 2018). Radu et al. (2012) reported detecting this pigment on a wavelength spectrum of 445, 472, $498 \mathrm{~nm}$. Meanwhile, it was detected by Mangunsong et al. (2019) at a wavelength spectrum of $460 \mathrm{~nm}$. Beta-carotene was also detected on the wavelength spectrum of 450.20 and 477.60 nm (Kusbandari and Susanti 2017). The literature showed that this pigment was detected in the leaves and roots of mangroves Avicennia officinalis, Excoecaria agallocha, Kandelia candel, and Rhizophora mucronata (Ravindran et al. 2012). In addition, it was also detected in the mangroves of Bruguiera gymnorrhiza, Sonneratia alba, and Xylocarpus granatum (Analuddin et al. 2019).

Pheophytin a pigment is a chlorophyll a without $\mathrm{Mg}^{2+}$ ion, and it is dominant in fresh green leaves, which is degraded due to heating and storage processes (Hsu et al. 2013). It is produced naturally by plant leaves and acts as an intermediary for the first electron carrier in the transfer pathway for photosystem II plants (Eijckelhoff and Dekker 1997). Bohn and Walczyk (2004) detected pheophytin-a on the wavelength spectrum of $405,661 \mathrm{~nm}$ while Kusmita et al. (2015) were on wavelength spectrum of 408, 505, 535, $609,665 \mathrm{~nm}$.

Violaxanthin is a natural xanthophyll pigment with an orange color found in various plants (Giossi et al. 2020). It is biosynthesized from zeaxanthin by an epoxidation reaction and has a 5,6-epoxy double group found in orange fruits, green vegetables, and microalgae (MelendezMartınez et al. 2008). Furthermore, it plays a role in photoprotection mechanisms such as the ability of plants to adapt to contrasting light environments (Bowen-O'Connor et al. 2013). Wang et al. (2018) detected violaxanthin pigments at the wavelength spectrum of 417.6, 440.9, and $470.1 \mathrm{~nm}$ while Ruban et al. (2001) detection was at 470 $\mathrm{nm}$. These pigments were also reported in mangroves with high salinity (Falqueto et al. 2008).

Neoxanthin pigments are carotenoids of xanthophylls groups. It acts as an intermediary for the biosynthesis of the hormone abscisic acid in plants (Perreau et al. 2020). Furthermore, it serves as a protection against photooxidative stress (Dall'Osto et al. 2007). Neoxanthin is the primary xanthophyll pigment found in green plants (Giossi et al. 2020). Chandrika et al. (2005) detected neoxanthin in the wavelength spectrum of 413, 436, 465 $\mathrm{nm}$, and was detected by Gupta et al. (2015) at 415, 437, $465 \mathrm{~nm}$. In mangroves, the neoxanthin pigment was found in mangroves Avicennia alba (Sasamoto et al. 2020).

The pigment detected in $R$. mucronata leaves extract predicted its probability to be active $(\mathrm{Pa})$ value as an antioxidant. Bioactivity prediction was conducted using PASS analysis (Filimonov et al. 2014). The $\mathrm{Pa}$ value describes the potential activity of a compound. When the $\mathrm{Pa}>0.7$, it is estimated to have a high bioactivity potential, both for computational and laboratory assays. Meanwhile, when the value is $0.3 \leq \mathrm{Pa} \leq 0.7$, then the compound has the computational ability as an antioxidant, but it has not been proven in the laboratory. Also, when the $\mathrm{Pa}<0.3$, it is predicted that the compound has a low bioactivity potential (Aisiah et al. 2020; Riyadi et al. 2021). However, the 
bioactivity of chlorophyll a and b may not be predicted by PASS analysis because they have a metal element in their structure. The pigments beta-carotene, lutein, neoxanthin, pheophytin-a, and violaxanthin have their potential bioactivity as antioxidants, free radical scavengers, and NF-E2-related factor (Nrf-2) stimulant. Figure 3 showed the probability to be active as the antioxidant of the pigment in the $R$. mucronata leaves extract.

Figure 3 showed that beta-carotene, lutein, neoxanthin, and violaxanthin are predicted to have potential as general antioxidants. Neoxanthin and violaxanthin were also predicted to be free radical scavengers. Meanwhile, betacarotene was predicted as an Nrf-2 stimulant, which regulates antioxidant protein as protection from oxidative damage (Ma 2013; Cui et al. 2016; Riyadi et al. 2019). Chlorophyll cannot be predicted by PASS analysis as an antioxidant, even though it has antioxidant properties as predicted by previous studies (İnanç 2011; Keleş et al. 2016; Sarker et al. 2018c; 2018d). Durga et al. (2015) reported chlorophyll a and $\mathrm{b}$ from medicinal plants with high potential antioxidants. Pérez-gálvez et al. (2020) stated that chlorophyll $b$ showed higher antioxidant activity than chlorophyll a.

Kurniawan et al. (2020) stated that lutein can act as an antioxidant and maintaining organs such as the eyes, brain, and skin. The content in marigold plant (Tagetes spp.) was reported to have a DPPH radical inhibition ability of $89.90 \%$ (Ingkasupart et al. 2015). Furthermore, it was reported to work as an antioxidant in the photo-stressed retina (Kamoshita et al. 2016)

Beta-carotene is also reported to be an antioxidant and an anti-carcinogen (Paolini et al. 2003). Berti et al. (2014) stated that it is effective as a radioprotective agent and acts as an antioxidant. Mueller and Boehm (2011) reported that beta-carotene and its derivatives showed antioxidant properties measured by the $\alpha \mathrm{TEAC}$, chemiluminescence (CL), and ferric reducing activity (FRAP) methods.
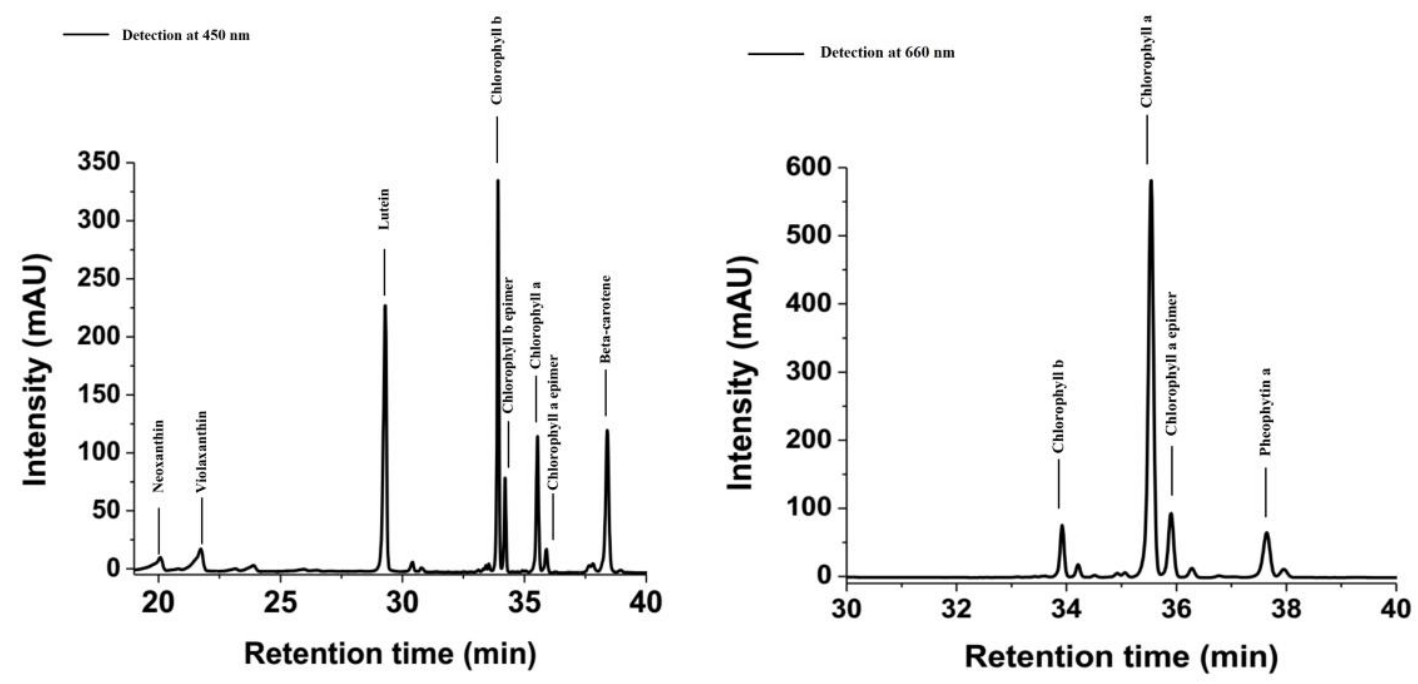

Figure 2. HPLC Chromatogram of Rhizophora mucronata leaves ethanol extract

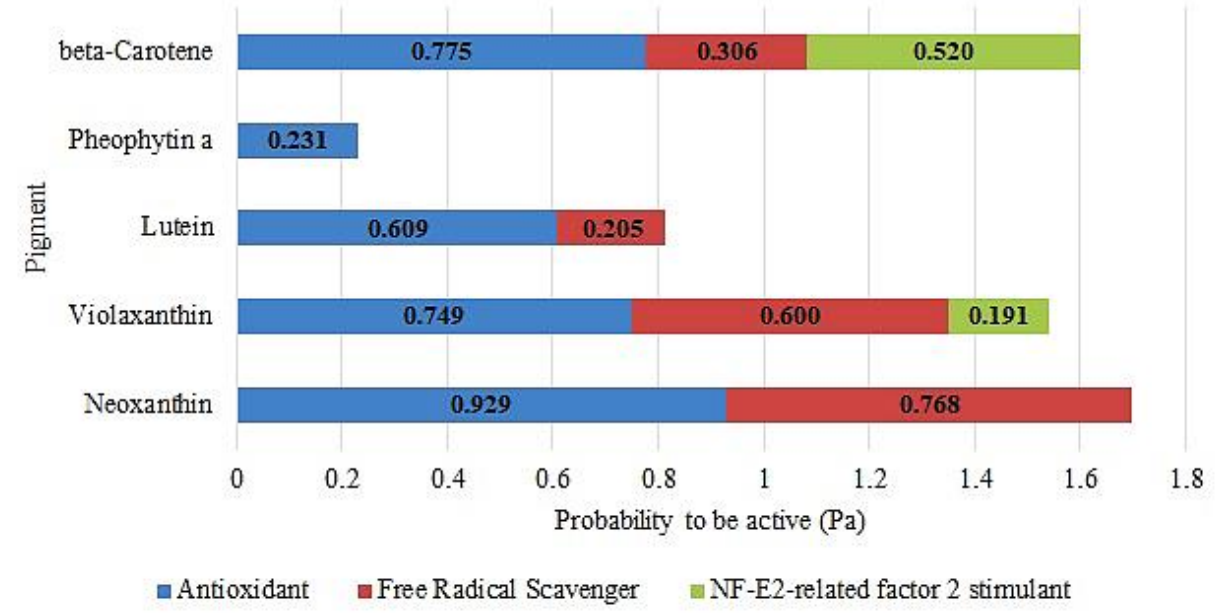

Figure 3. Probability to be active of pigments contain in Rhizophora mucronata leaves as an antioxidant with PASS analysis 
Furthermore, Figure 3 showed the prediction of betacarotene bioactivity as an Nrf-2 stimulant. The literature showed beta-carotene can activate the Nrf2-ARE (antioxidant response element) pathway to provide a neuroprotective effect from traumatic brain injury (Chen et al. 2019). Ben-dor et al. (2005) reported that beta-carotene stimulates Nrf-2 in the leukemia promyelocytic core body and regulates phase II enzyme expression (associated with cancer-preventing gene activation).

Dall'Osto et al. (2007) stated that neoxanthin acts as an antioxidant in the photosystem II supercomplex in plant thylakoid to protect membrane lipids photooxidation. In addition, Giossi et al. (2020) reported that neoxanthin was directly involved in photoprotection as an antioxidant to increase the activity of ROS scavenge under extreme light conditions. Sarker and Oba (2020g) reported that the neoxanthin contained in Amaranthus tricolor showed DPPH radical scavenging activity. Neoxanthin reduces oxidative-induced DNA base damage by less than $50 \%$. In lower concentrations than lutein, it is a better inhibitor of oxidative-induced DNA damage (Şahin et al. 2020).

Dall'Osto et al. (2007) also reported the antioxidant properties of violaxanthin as photoprotection, even though it is lower than neoxanthin. The literature also reports the antioxidant properties of violaxanthin and its derivatives isolated from mangoes, with strong lipid peroxidation inhibition capabilities (Araki et al. 2016). Furthermore, violaxanthin isolated from microalgae Eustigmatos cf. polyphem was also reported to have radical scavenger capabilities with 2,2-diphenyl-1-picrylhydrazyl (DPPH), and 2,2-azobis-3-ethylbenzthiazoline-6-sulphonic acid (ABTS) radical assays (Wang et al. 2018). However, Figure 2 showed that pheophytin a has a low $\mathrm{Pa}$ value as an antioxidant, and it prevents oxidative DNA damage and lipid peroxidation. It works by reducing reactive oxygen species, such as DPPH, and by chelation of metal ions, such as Fe (II) (Hsu et al. 2013). Kusmita et al. (2015) also reported that pheophytin a contained in green tea has an antioxidant capacity (DPPH method) with $\mathrm{IC}_{50}=573 \pm$ $0.23 \mathrm{mg} / \mathrm{L}$.

The mechanism of antioxidant action of the pigments in $R$. mucronata leaves extract should be properly understood Furthermore, the pigments in Table 1 were evaluated by STITCH. This is a tool for integrating information about the interactions of metabolic pathways, crystal structure, binding experiments, and relationships between chemicals (Kuhn et al. 2008). Figure 4 showed the interactions between the pigments.

Figure 4 showed the interaction between the working mechanism of the pigments in the $R$. mucronata leaves extract. Chlorophyll a, chlorophyll b, neoxanthin, and violaxanthin support the performance of lutein and betacarotene. Furthermore, Beta-carotene pigments activate and catalyze the transcriptional regulation of the BCMO1 protein (beta, beta-Carotene 15,15'-monooxygenase-1), which is a key enzyme in vitamin A metabolism (Lietz et al. 2010). BCMO1 was reported to be expressed in intestinal tissue and plays a role in lipid metabolism (Lietz et al. 2012). It affects the RBP2 protein (Retinol-binding protein 2), which plays a role in the absorption and metabolism of intracellular vitamin A (Blaner et al. 2020). Figure 4 showed that lutein affects the expression of BCO2 (Beta, beta-carotene 9 ', 10'-oxygenase) to catalyze beta carotene. In addition, Lietz et al. (2012) also reported that $\mathrm{BCO} 2$ contributes to the formation of vitamin A to improve antioxidant performance and immune function (Zhang et al. 2019).

Figure 4 also showed that lutein affects the PPARA gene (Peroxisome proliferator-activated receptor alpha), which strengthens antioxidant and anti-inflammatory defense systems (Moran et al. 2014) by increasing regulation of the enzyme expression and inhibiting the activity of NF- $\mathrm{NB}$ (nuclear factor kappa b) (Gao and $\mathrm{Li}$ 2012). PPARA activates BCMO1 to metabolize vitamin A. It also regulates the expression of SCARB1 (scavenger receptor class B type 1), which is an HDL (high-density lipoprotein) receptor protein that mediates carotenoid uptake (Hoekstra and Sorci-Thomas 2017). Soran et al. (2015) reported that HDL showed an antioxidant effect in protecting oxidative stress due to increased LDL (lowdensity lipoprotein). Figure 4 showed that lutein affects UCP1 (uncoupling protein 1) expression directly or through activation by PPARA. UCP1 gene reduces the production of ROS (reactive oxygen species) in mitochondria (Oelkrug et al. 2014) to prevent oxidative stress in adipose tissue (Shabalina et al. 2006).

Figure 4 showed beta-carotene affects BDNF (Brainderived neurotrophic factor) expression and it is a gene in the brain that promotes the survival of nerve cells (neurons) by playing a role in the growth, maturation (differentiation), and maintenance of neuron cells. Wu et al. (2016) reported that BDNF increases superoxide dismutases and glutathione reductase expression. It also reduces the oxidative protein damage index (Lee et al. 2009), reduces antioxidant protein expression ( $\mathrm{Wu}$ et al. 2012), restores reduced mitochondrial electron-coupling capacity, and increases mitochondrial uncoupling protein 2 (UCP2). It acts as an antioxidant by reducing the production of superoxide anions (Chan et al. 2010). Figure 4 also showed that beta-carotene and lutein inhibit the activation of the protein MMP9 (Matrix Metalloproteinase9) through increased BDNF expression. Furthermore, the MMP9 gene regulates the tissue remodeling process by activating cytokines and chemokines, causing inflammation and fibrosis in the tissue (Yabluchanskiy et al. 2013). Figure 4 showed that beta-carotene activates FN1 (Fibronectin 1) action to inhibit the enzyme lipoxygenases (LOX) and MMP9 expression. LOX enzyme oxidizes fatty acids and causes inflammation in tissues (Ratnasari et al. 2017). Meanwhile, FN1 is activated through the Nrf-2 pathway (Prestigiacomo and Suter-Dick 2018) to bind LOX. Oxidation and inflammation in the tissue can be inhibited (Fogelgren et al. 2005). In summary, the pigments in the leaves of $R$. mucronata work synergistically by activating antioxidant enzymes and inhibiting the expression of oxidative stress proteins.

The extract of $R$. mucronata leaves was evaluated for its antioxidant capacity as a free radical scavenger using the DPPH method. Meanwhile, DPPH is a stable free radical which accepts electrons or hydrogen atoms to form 
stable diamagnetic molecules (Tanod et al. 2019a). The antioxidant capacity was evaluated by calculating DPPH purple light intensity level proportional to the decrease in DPPH concentration. This reduction was caused by the reaction of the 2,2-diphenyl-1-picrylhydrazyl molecule with the hydrogen atoms released by the components of the sample molecule. It formed hydrazine diphenyl picril compound and caused DPPH to change color from purple to yellow (Tanod et al. 2019b). The reactivity of the $R$. mucronata leaves extract with stable free radicals was also evaluated, and the antioxidant capacity was compared with vitamin C (Figure 5). In addition, Vitamin $\mathrm{C}$ is commonly used to compare assaying antioxidant activity because it is cheaper and easier to obtain (Lung and Destiani 2014).

Figure 5 showed that the $R$. mucronata leaves extract has antioxidant activity because hydrogen atoms or electrons were donated to react with DPPH radicals.
Increased concentration of the extract also increased the percentage of DPPH free radical inhibition. Table 2 showed that the inhibition percentage was evaluated for $\mathrm{IC}_{50}$ determination by probit analysis. According to the Blois (1958) category, antioxidant activity can be categorized as very strong ( $\left.\mathrm{IC}_{50}<50 \mu \mathrm{g} / \mathrm{mL}\right)$, strong $(50 \leq$ $\left.\mathrm{IC}_{50} \leq 100 \mu \mathrm{g} / \mathrm{mL}\right)$, moderate $\left(100 \leq \mathrm{IC}_{50} \leq 150 \mu \mathrm{g} / \mathrm{mL}\right)$, weak $\left(150 \leq \mathrm{IC}_{50} \leq 200 \mu \mathrm{g} / \mathrm{mL}\right)$, and very weak $\left(\mathrm{IC}_{50}>200\right.$ $\mu \mathrm{g} / \mathrm{mL})$.

Table 2. The $\mathrm{IC}_{50}$ value of the Rhizophora mucronata leaves extract using the DPPH method was compared with vitamin C

\begin{tabular}{ll}
\hline Sample & IC $_{\mathbf{5 0}}(\boldsymbol{\mu g} / \mathbf{m L})$ \\
\hline$R$. mucronata leaves & $20.99 \pm 0.33$ \\
Vitamin C & $9.62 \pm 0.09$
\end{tabular}

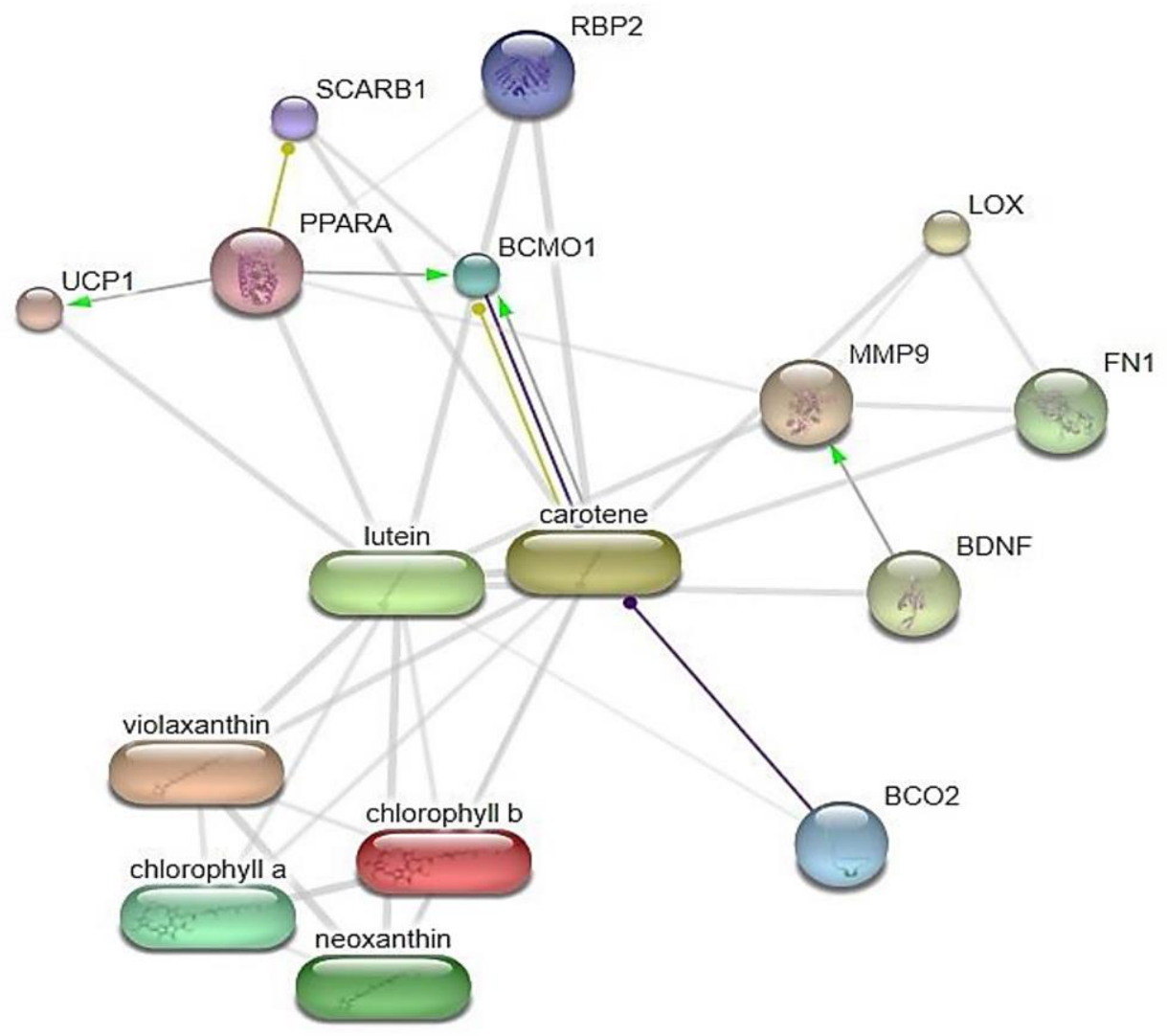

\begin{tabular}{|c|c|c|c|c|}
\hline \multicolumn{5}{|l|}{ Nodes: } \\
\hline $\begin{array}{l}\text { Network nodes represent proteins } \\
\text { splice isoforms or post-translational } \\
\text { modifications are collapsed, ie. each node } \\
\text { represents all the proteins produced by a } \\
\text { single, protein-coding gene locus. }\end{array}$ & \multicolumn{2}{|c|}{$\begin{array}{l}\text { small nodes: } \\
\text { protein of unknown } 3 D \text { structure } \\
\text { af large nodes: } \\
\text { some } 3 D \text { structure is known or predicted }\end{array}$} & \multicolumn{2}{|c|}{$\begin{array}{l}\text { (39) colored nodes: } \\
\text { query proteins and first shell of interactors } \\
\text { (4) white nodes: }\end{array}$} \\
\hline \multicolumn{5}{|l|}{ Edges: } \\
\hline \multicolumn{2}{|c|}{$\begin{array}{l}\text { Edges represent protein-protein associations } \\
\text { associations are meant to be specific and meaningful, ie. } \\
\text { proteins jointly contribute to a shared function, this does not } \\
\text { necessarily mean they are physically binding each other. }\end{array}$} & \multicolumn{2}{|c|}{ 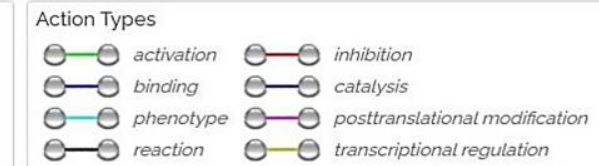 } & $\begin{array}{l}\text { Action effects } \\
\Theta \rightarrow \odot \text { positive } \\
\Theta-\Theta \text { negative } \\
\ominus \rightarrow \odot \text { unspecified }\end{array}$ \\
\hline
\end{tabular}

Figure 4. Mechanism action as an antioxidant of pigments in Rhizophora mucronata leaves with STITCH analysis 


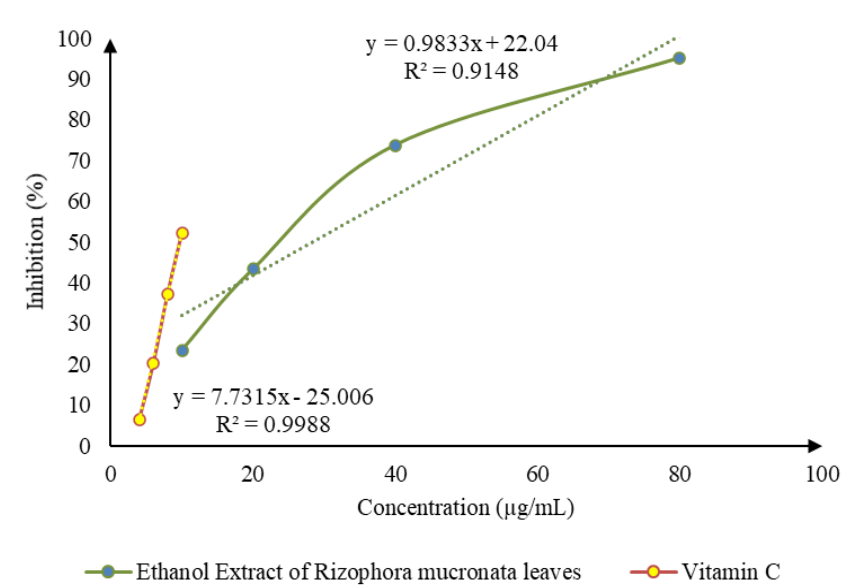

Figure 5. DPPH radical inhibition from the Rhizophora mucronata leaves extract compared to vitamin $\mathrm{C}$

Table 2 showed that the $R$. mucronata leaves extract and vitamin $C$ had very strong antioxidant activity, with a DPPH concentration of $0.76 \mathrm{mM}$. Literature studies showed that the $\mathrm{IC}_{50}$ of the same sample can vary depending on the DPPH concentration, sample origin, conditions, and the solvent used (Dewanto et al. 2019). Furthermore, fractionation and crude extract of $R$. mucronata mature leaves from Penunggul, East Java, Indonesia showed $\mathrm{IC}_{50}$ from $82.97 \pm 51.15$ to $491.78 \pm$ $427.59 \mu \mathrm{g} / \mathrm{mL}$, while the $\mathrm{IC}_{50}$ ascorbic acid (vitamin $\mathrm{C}$ ) was $12.36 \mu \mathrm{g} / \mathrm{mL}$, with a DPPH concentration of $0.4 \mathrm{mM}$ (Sasmito et al. 2016). The ethanol extract obtained from Sunderban, India, was reported to show DPPH radical scavenging $\left(\mathrm{IC}_{50}\right) 6.65 \pm 0.10 \mu \mathrm{g} / \mathrm{mL}$, with a $\mathrm{DPPH}$ concentration of $0.135 \mathrm{mM}$ (Adhikari et al. 2016). Two compounds isolated from the methanol extract of the leaves from Vallarpadam, India, showed $\mathrm{IC}_{50}$ of 0.76-0.84 $\mathrm{mg} / \mathrm{mL}$, with DPPH $0.1 \mathrm{mM}$ (Chakraborty and Raola 2017). Furthermore, the leaves extract from Tugurejo, Central Java, Indonesia, was reported to have $\mathrm{IC}_{50}$ of 113.41 ppm (methanol), 151.13 ppm (n-hexane), 184.78 ppm (ethyl acetate), with a DPPH concentration of $0.1 \mathrm{mM}$ (Ridlo et al. 2017). The ethanol extract obtained from the coast of Palu Bay showed an $\mathrm{IC}_{50}$ of $103.95 \pm 0.38 \mu \mathrm{g} / \mathrm{mL}$, with a DPPH concentration of $50 \mu \mathrm{M}$ (Dewanto et al. 2018). Furthermore, stick balm preparations from methanol extract of $R$. mucronata showed $\mathrm{IC}_{50}$ of $57.40,57.14$, and $77.32 \mathrm{ppm}$, with a DPPH concentration of $0.004 \%$ (Faiqoh et al. 2020).

Literature studies reported varying $\mathrm{IC}_{50}$ values of vitamin $\mathrm{C}$ with different $\mathrm{DPPH}$ concentrations. The $\mathrm{IC}_{50}$ of vitamin $C$ with a DPPH concentration of $0.1 \mathrm{mM}$, was 3.90 $\mu \mathrm{g} / \mathrm{mL}$ (Pratiwi et al. 2013) and $4.76 \mu \mathrm{g} / \mathrm{mL}$ (Widyowati et al. 2014). Isnindar et al. (2016) reported an $\mathrm{IC}_{50}$ with a DPPH concentration of $0.4 \mathrm{mM}$ to be $1.83 \mu \mathrm{g} / \mathrm{mL}$. Aliyu et al. (2017) reported an $\mathrm{IC}_{50}$ with a DPPH concentration of $0.2 \mathrm{mM}$ to be $13.89 \mu \mathrm{g} / \mathrm{mL}$. Meanwhile, Johnson et al. (2017) reported an $\mathrm{IC}_{50}$ with a DPPH concentration of $0.004 \%(\mathrm{w} / \mathrm{v})$ to be $37.50 \mu \mathrm{g} / \mathrm{mL}$. Najihudin et al. (2017) reported an $\mathrm{IC}_{50}$ with a $\mathrm{DPPH}$ concentration of $0.01 \%$ (w/v) to be $4.71 \mu \mathrm{g} / \mathrm{mL}$. Dewanto et al. (2019) reported an $\mathrm{IC}_{50}$ of vitamin $\mathrm{C}$ with a DPPH concentration of $50 \mu \mathrm{M}$ to be $31.35 \pm 0.81 \mu \mathrm{g} / \mathrm{mL}$.

Mangroves are plants that live in tidal areas, and they experience variations in environmental pressure. In addition, variations in ecological pressure trigger reactive oxygen species (ROS) production and interfere with mangrove growth (Dasgupta et al. 2012). The pigments contained in mangroves produce antioxidant substances useful for the self-defense mechanism of ROS (Thatoi et al. 2014; Sarker and Oba 2018c; Dewanto et al. 2021). Therefore, it can be concluded that chlorophyll a, chlorophyll b, beta-carotene, lutein, neoxanthin, pheophytin a, and violaxanthin are the pigment profiles in Rhizophora mucronata mangrove leaves. All pigments detected have strong potential as antioxidants, especially as free radical scavengers and Nrf-2 stimulants. They interact with each other to inactivate antioxidant enzymes and inhibit the expression of oxidative stress proteins. This study showed that the pigment in $R$. mucronata leaves is a potential source of antioxidants for human health. Furthermore, it was developed by isolating the pigments from Rhizophora mucronata leaves and comparing the antioxidant power with standards for nutraceuticals and pharmaceuticals preparation.

\section{ACKNOWLEDGEMENTS}

The authors are grateful to the Rector of Universitas Sam Ratulangi, Manado, Indonesia for research grant No. 042.01.2.400959/2019 (Universitas Sam Ratulangi DIPA research funding), and are also grateful to Andreas Marbun and Maikel Tiolung for their assistance.

\section{REFERENCES}

Adhikari A, Ray M, Das AK, Sur TK. 2016. Antidiabetic and antioxidant activity of Rhizophora mucronata leaves (Indian sundarban mangrove): An in vitro and in vivo study. J Res Ayurveda 37 (1): 76 81. DOI: 10.4103/ayu.AYU.

Aisiah S, Olga, Tanod WA, Salosso Y, Bambang, Riyadi PH. 2020. Computational analysis of ethyl acetate extract of Nauclea subdita (Korth.) Steud. leaves as peptidoglycan glycosyltransferase inhibitor in Aeromonas hydrophila. IOP Conf Ser: Earth Environ Sci 584 (1): 012022. DOI: 10.1088/1755-1315/584/1/012022.

Al-ali RM, Al-hilifi SAH, Al-Mossawi AEHJ. 2020. Extraction of lutein from some plant source in different conditions and application in food system. Plant Arch 20 (1): 1679-1685.

Alhaddad ZA, Wahyudi D, Tanod WA. 2019. Antibacterial bioactivity of mangrove leaf extracts Avicennia sp. Jurnal Kelautan: Indones J Mar Sci Technol 12 (1): 12-22. DOI: 10.21107/jk.v12i1.4752. [Indonesian]

Aliyu M, Abdullahi A, Ugya A. 2017. Antioxidant properties of selected poaceae species in Kano, Northern Nigeria. Eur J Biomed Pharm Sci 4 (5): 577-585.

Aljaghthmi OH, Heba HM, Abu Zeid IM. 2017. Bioactive compounds extracted from mangrove plants (Avicennia marina and Rhizophora mucronata): an overview. Adv Biol Res 11: 161-170. DOI: 10.1016/j.pathophys.2018.09.002

Analuddin K, Septiana A, Nasaruddin, Sabilu Y, Sharma S. 2019. Mangrove fruit bioprospecting: nutritional and antioxidant potential 
as a food source for coastal communities in the Rawa Aopa Watumohai National Park, Southeast Sulawesi, Indonesia. Intl J Fruit Sci 19 (4): 423-436. DOI: 10.1080/15538362.2018.1555507.

Andriani D, Revianti S, Prananingrum W. 2020. Identification of compounds isolated from a methanolic extract of Acanthus ilicifolius leaves and evaluation of their antifungal and antioxidant activity. Biodiversitas 21 (6): 2521-2525. DOI: 10.13057/biodiv/d210625.

Araki M, Kaku N, Harada M, Ando Y, Yamaguchi R, Shindo K. 2016. Production of auroxanthins from violaxanthin and 9-cis-violaxanthin by acidic treatment and the antioxidant activities of violaxanthin, 9 cis-violaxanthin, and auroxanthins. J Agric Food Chem 64 (49): 9352-9355. DOI: 10.1021/acs.jafc.6b04506.

Aruldass CA, Dufossé L, Ahmad WA. 2018. Current perspective of yellowish-orange pigments from microorganisms-a review. J Cleaner Prod 180: 168-182. DOI: 10.1016/j.jclepro.2018.01.093.

Bandaranayake WM. 1998. Traditional and medicinal uses of mangroves. Mangroves Salt Marshes 2 (3): 133-148. DOI: 10.1023/A:1009988607044.

Banerjee K, Chowdhury GR, Mitra A. 2017. Astaxanthin level of dominant mangrove floral species in Indian Sundarbans. MOJ Bioorg Org Chem 1 (2): 1-5. DOI: 10.15406/mojboc.2017.01.00008.

Ben-dor A, Steiner M, Gheber L, Danilenko M, Dubi N, Linnewiel K, Zick A, Sharoni Y, Levy J. 2005. Carotenoids activate the antioxidant response element transcription system. Mol Cancer Ther 4 (1): 177 187.

Berti AP, Düsman E, Mariucci RG, Lopes NB, Vicentini VEP. 2014 Antimutagenic and radioprotective activities of beta-carotene agains the biological effects of iodine-131 radiopharmaceutical in wistar rats. Genet Mol Res 13 (1): 2248-2258. DOI: 10.4238/2014.March.31.5.

Blaner WS, Brun PJ, Calderon RM, Golczak M. 2020. Retinol-binding protein 2 (RBP2): biology and pathobiology. Crit Rev Biochem Mol Biol 55 (2): 197-218. DOI: 10.1080/10409238.2020.1768207.

Blois M. 1958. Antioxidant determinations by the use of a stable free radical. Nature 181 (4617): 1199-1200. DOI: 10.1038/1811199a0.

Bogacz-Radomska L, Harasym J. 2018. $\beta$-Carotene-properties and production methods. Food Qual Saf 2 (2): 69-74. DOI: 10.1093 /fqsafe/fyy004.

Bohn T, Walczyk T. 2004. Determination of chlorophyll in plant samples by liquid chromatography using zinc-phthalocyanine as an internal standard. J Chromatogr A 1024 (1-2): 123-128. DOI 10.1016/j.chroma.2003.10.067.

Bowen-O'Connor CA, VanLeeuwen DM, Bettmann G, Sterling TM, Hilaire RSt. 2013. Variation in violaxanthin and lutein cycle components in two provenances of Acer grandidentatum L. exposed to contrasting light. Acta Physiol Plant 35 (2): 541-548. DOI 10.1007/s11738-012-1095-7.

Chakraborty K, Raola VK. 2017. Two rare antioxidant and antiinflammatory oleanenes from loop root Asiatic mangrove Rhizophora mucronata. Phytochemistry 135: 160-168. DOI: 10.1016/j.phytochem.2016.12.013.

Chan SHH, Wu CWJ, Chang AYW, Hsu Ksen, Chan JYH. 2010. Transcriptional upregulation of brain-derived neurotrophic factor in rostral ventrolateral medulla by angiotensin II: significance in superoxide homeostasis and neural regulation of arterial pressure. Circ Res 107 (9): 1127-1139. DOI: 10.1161/CIRCRESAHA.110.225573.

Chandrika UG, Jansz ER, Warnasuriya ND. 2005. Identification and HPLC quantification of carotenoids of the fruit pulp of Chrysophyllum roxburghii. J Nat Sci Found Sri Lanka 33 (2): 93-98. DOI: 10.4038/jnsfsr.v33i2.2337.

Chen P, Li L, Gao Y, Xie Z, Zhang Y, Pan Z, Tu Y, Wang H, Han Q, Hu $X$, Xin $X$. 2019. $\beta$-carotene provides neuro protection after experimental traumatic brain injury via the Nrf2-ARE pathway. J Integr Neurosci 18: 153-161. DOI: 10.31083/j.jin.2019.02.120.

Croft H, Chen JM. 2017. Leaf Pigment Content. Elsevier Inc, Canada DOI: 10.1016/B978-0-12-409548-9.10547-0.

Cui T, Lai Y, Janicki JS, Wang X. 2016. Nuclear factor erythroid-2 related factor 2 (Nrf2)-mediated protein quality control in cardiomyocytes. Front Biosci 21: 192-202. DOI: 10.2741/4384

Dahdouh-Guebas F, Mathenge C, Kairo JG, Koedam N. 2000. Utilization of mangrove wood products around Mida Creek "Kenya" amongst subsistence and commercial users. Econ Bot 54 (4): 513-527. DOI: 10.1007/BF02866549

Dall'Osto L, Cazzaniga S, North H, Marion-Poll A, Bassia R. 2007. The arabidopsis aba4-1 mutant reveals a specific function for neoxanthin in protection against photooxidative stress. Plant Cell 19 (3): 1048 1064. DOI: $10.1105 /$ tpc. 106.049114
Dasgupta N, Nandy P, Sengupta C, Das S. 2012. Protein and enzymes regulations towards salt tolerance of some Indian mangroves in relation to adaptation. Trees Struct Funct 26 (2): 377-391. DOI: 10.1007/s00468-011-0599-x.

Dewanto DK, Finarti F, Hermawan R, Ndobe S, Riyadi PH, Tanod WA. 2019. Antioxidant activity of soft coral extract from Palu Bay, Central Sulawesi, Indonesia. Jurnal Pascapanen dan Bioteknologi Kelautan dan Perikanan 14 (2): 163-178. DOI: 10.15578/jpbkp.v14i2.583 [Indonesian]

Dewanto DK, Hermawan R, Muliadin, Riyadi PH, Aisiah S, Tanod WA. 2021. GC-MS profile of Rhizophora apiculata leaf extract from the coast of Tomini bay, Central Sulawesi with antibacterial and antioxidant activity. Jurnal Kelautan: Indon J Mar Sci Techno 14 (1): 30-42. [Indonesian]

Dewanto DK, Tanod WA, Finarti F, Renol R. 2018. Screening of antiradical activity from some Central Sulawesi mangroves. Pharmaciana 8 (1): 155-168. DOI: 10.12928/pharmaciana.v8i1.8187.

Dou Z, Cui L, Li J, Zhu Y, Gao C, Pan X, Lei Y, Zhang M, Zhao X, Li W. 2018. Hyperspectral estimation of the chlorophyll content in shortterm and long-term restorations of Mangrove in Quanzhou Bay Estuary, China. Sustainability 10 (4): 1-15. DOI: $10.3390 /$ su 10041127

Durga Devi M, Banu N. 2015. Study of antioxidant activity of chlorophyll from some medicinal plants. Indian J Res 4 (2): 6-8.

Eijckelhoff C, Dekker JP. 1997. A routine method to determine the chlorophyll a, pheophytin a and B-carotene contents of isolated Photosystem II reaction center complexes. Photosynth Res 52 (1): 6973. DOI: $10.1023 / \mathrm{A}: 1005834006985$.

Faiqoh M, Utami TFY, Pertiwi Y. 2020. Antioxidant assay for stick balm preparation of Rhizophora mucronata leaf extract using DPPH method. Jurnal Ilmiah Jophus: J Pharma UMUS 2 (1): 51-58. [Indonesian]

Falqueto A, Silva DM, Fontes RV. 2008. Photosynthetic performance of mangroves Rhizophora mangle and Laguncularia racemosa under field conditions. Rev Árvore 32 (3): 577-582. DOI: 10.1590/S010067622008000300018

Filimonov DA, Lagunin AA, Gloriozova TA, Rudik AV, Druzhilovskii DS, Pogodin PV, Poroikov VV. 2014. Prediction of the biological activity spectra of organic compounds using the pass online web resource. Chem Heterocyclic Compd 50 (3): 444-457. DOI: 10.1007/s10593-014-1496-1.

Flores-de-Santiago F, Kovacs JM, Wang J, Flores-Verdugo F, Zhang C, González-Farías F. 2016. Examining the influence of seasonality, condition, and species composition on mangrove leaf pigment contents and laboratory based spectroscopy data. Remote Sens 8 (3): 226-246. DOI: 10.3390/rs8030226.

Fogelgren B, Polgár N, Szauter KM, Újfaludi Z, Laczkó R, Fong KSK, Csiszar K. 2005. Cellular fibronectin binds to lysyl oxidase with high affinity and is critical for its proteolytic activation. J Biol Chem 280 (26): 24690-24697. DOI: 10.1074/jbc.M412979200.

Gao Z, Li YH. 2012. Antioxidant stress and anti-inflammation of PPAR $\alpha$ on warm hepatic ischemia-reperfusion injury. PPAR Res 2012: 1-8. DOI: $10.1155 / 2012 / 738785$

Giossi CE, Cartaxana P, Cruz S. 2020. Photoprotective role of neoxanthin in plants and algae. Molecules 25 (20): 4617-4633. DOI: 10.3390/molecules25204617.

Gupta P, Sreelakshmi Y, Sharma R. 2015. A rapid and sensitive method for determination of carotenoids in plant tissues by high performance liquid chromatography. Plant Methods 11 (1): 1-12. DOI: 10.1186/s13007-015-0051-0.

Hegazi MM, Perez-ruzafa A, Almela L, Candela ME. 1998. Separation and identification of chlorophylls and carotenoids from Caulerpa prolifera, Jania rubens and Padina pavonica by reversed-phase highperformance liquid chromatography. J Chromatogr A 829 (1-2): 153 159. DOI: 10.1016/S0021-9673(98)00803-6.

Henriques M, Silva A, Rocha J. 2007. Extraction and quantification of pigments from a marine microalga: a simple and reproducible method. In: Mendez-Vilas A (ed) Communicating Current Research and Educational Topics and Trends in Applied Microbiology. Formatex Research Center, Badajoz.

Hoekstra M, Sorci-Thomas M. 2017. Rediscovering scavenger receptor type BI: surprising new roles for the HDL receptor. Curr Opin Lipidol 28 (3): 255-260. DOI: 10.1097/MOL.0000000000000413.

Hsu CY, Chao PY, Hu SP, Yang CM. 2013. The antioxidant and free radical scavenging activities of chlorophylls and pheophytins. Food Nutr Sci 4: 1-8. DOI: 10.4236/fns.2013.48a001. 
Imdadul H, Wirakarnain S, Koshy P, Arash R, Shariff HABM, Mat TR. 2011. Valuable antioxidant and antimicrobial extracts from Rhizophora mucronata of Asiatic mangrove forests. Res J Biotechnol 6 (1): 10-14.

İnanç AL. 2011. Chlorophyll: structural properties, health benefits and its occurrence in virgin olive oils. Akademik Gida 9: 26-32.

Ingkasupart P, Manochai B, Song WT, Hong JH. 2015. Antioxidant activities and lutein content of 11 marigold cultivars (Tagetes spp.) grown in Thailand. Food Sci Technol 35 (2): 380-385. DOI: 10.1590/1678-457X.6663.

Isnindar, Wahyuono S, Widyarini S, Yuswanto. 2016. Determination of antioxidant activities of buas-buas leaves (Premna serratifolia L.) using DPPH (2,2-diphenyl-1-picrylhydrazyl) method. Tradit Med J 21 (3): 111-115. DOI: 10.22146/tradmedj.17292.

Jariyah, Widjanarko SB, Yunianta, Estiasih T, Sopade PA. 2014. Pasting properties mixtures of mangrove fruit flour (Sonneratia caseolaris) and starches. Int Food Res J 21 (6): 2161-2167.

Jeffrey SW, Mantoura RFC, Wright SW. 1997. Phytoplankton Pigments in Oceanography: Guidelines to Modern Methods. UNESCO Publishing, Paris

Johnson E, Etim E, Archibong E. 2017. Isolation and anti-oxidant potentials of parahydroxybenzaldehyde from the methanol leaf extract of Aspilia africana (Pers.) C.D. Adams (Asteraceae). Niger J Pharm Appl Sci Res 6 (1): 26-32.

Kamoshita M, Toda E, Osada H, Narimatsu T, Kobayashi S, Tsubota K, Ozawa Y. 2016. Lutein acts via multiple antioxidant pathways in the photo-stressed retina. Sci Rep 6 (1): 1-10. DOI: 10.1038/srep30226.

Kardiman, Ridhwan M, Armi. 2017. Lindur fruit (Bruguiera gymnorrhiza) as food for the Acehnese community. Serambi Saintia 5 (2): 51-55. [Indonesian]

Keleş D, Özgen Ş, Saraçoğlu O, Ata A, Özgen M. 2016. Antioxidant potential of Turkish pepper (Capsicum annuиm L.) genotypes at two different maturity stages. Turk J Agric For 40 (4): 542-551. DOI 10.3906/tar-1601-24

Kepel TL, Suryono DD, Ati RNA, Salim HL, Hutahaean AA. 2017 Important value and economic value estimation of carbon storage of mangrove vegetation in Kema, North Sulawesi. Jurnal Kelautan Nasional 12 (1): 19-26. DOI: 10.15578/jkn.v12i1.6170. [Indonesian]

Kuhn M, Von Mering C, Campillos M, Jensen LJ, Bork P. 2008 STITCH: Interaction networks of chemicals and proteins. Nucleic Acids Res 36 (1): 684-688. DOI: 10.1093/nar/gkm795.

Kurniawan JM, Yusuf MM, Heriyanto, Panintingjati TH, Brotosudarmo. 2020. Literature review on the potential of lutein from local marigold flowers as a health supplement. Media Penelitian dan Pengembangan Kesehatan 30 (2): 147-162. DOI: $10.22435 / m p k . v 30 i 2.2874$ [Indonesian]

Kusbandari A, Susanti H. 2017. Beta carotene content and free radical scavenging activity of cantaloupe (Cucumis melo var. Cantalupensis L.) extract against DPPH (1,1-diphenyl-2-picrylhydrazyl) using UVvisible spectrophotometry method. Jurnal Farmasi Sains dan Komunitas 14 (1): 37-42. DOI: 10.24071/jpsc.141562. [Indonesian]

Kusmita L, Puspitaningrum I, Limantara L. 2015. Identification, isolation and antioxidant activity of pheophytin from green tea (Camellia sinensis (L.) Kuntze). Procedia Chem 14: 232-238. DOI: 10.1016/j.proche.2015.03.033.

Landrum JT, Bone RA. 2001. Lutein, zeaxanthin, and the macular pigment. Arch Biochem Biophys 385 (1): 28-40. DOI: 10.1006/abbi.2000.2171

Lee B, Cao R, Choi YS, Cho HY, Rhee AD, Hah CK, Hoyt KR, Obrietan K. 2009. The CREB/CRE transcriptional pathway: protection against oxidative stress-mediated neuronal cell death. J Neurochem 108 (5) 1251-1265. DOI: 10.1111/j.1471-4159.2008.05864.x.

Lichtenthaler HK. 1987. Chlorophylls and carotenoids: pigments of photosynthetic biomembranes. In: Khan MU, Mitchell K (eds) Methods in Enzymology. Academic Press Inc., Cambridge. DOI: 10.1016/0076-6879(87)48036-1

Lietz G, Lange J, Rimbach G. 2010. Molecular and dietary regulation of $\beta, \beta$-carotene 15,15'-monooxygenase 1 (BCMO1). Arch Biochem Biophys 502 (1): 8-16. DOI: 10.1016/j.abb.2010.06.032.

Lietz G, Oxley A, Boesch-Saadatmandi C, Kobayashi D. 2012 Importance of $\beta, \beta$-carotene $15,15^{\prime}$-monooxygenase 1 (BCMO1) and $\beta, \beta$-carotene $9^{\prime}, 10^{\prime}$-dioxygenase 2 (BCDO2) in nutrition and health. Mol Nutr Food Res 56 (2): 241-250. DOI: 10.1002/mnfr.201100387.

Limantara L, Heriyanto. 2012. Pigment composition and content of fookosantin brown seaweed from madura waters with high performance liquid chromatography. Ilmu Kelautan: Indones J Mar Sci 15 (1): 23-32. DOI: 10.14710/ik.ijms.15.1.23-32. [Indonesian]

Liu Y. 2012. Spectral response to varying levels of leaf pigments collected from a degraded mangrove forest. J Appl Remote Sens 6 (1): 063501. DOI: $10.1117 / 1$.jrs.6.063501

Lung JKS, Destiani DP. 2014. Antioxidant activity test of vitamins A, C, E with the DPPH method. Farmaka 14 (1): 1-10. [Indonesian]

Ma Q. 2013. Role of Nrf2 in oxidative stress and toxicity. Annu Rev Pharmacol Toxicol 53: 401-426. DOI: 10.1146/annurev-pharmtox011112-140320.Role.

Mangunsong S, Assiddiqy R, Sari EP, Marpaung PN, Sari RA. 2019. Determination of $\beta$-carotene in carrots (Daucus carota) by high performance liquid chromatography (U-HPLC). AcTion: Aceh Nutr J 4: 36-41. DOI: 10.30867/action.v4i1.151. [Indonesian]

Mapari SAS, Nielsen KF, Larsen TO, Frisvad JC, Meyer AS, Thrane, U. 2005. Exploring fungal biodiversity for the production of watersoluble pigments as potential natural food colorants. Curr Opin Biotechnol 16 (2): 231-238. DOI: 10.1016/j.copbio.2005.03.004.

Melendez-Martınez AJ, Britton G, Vicario IM, Heredia FJ. 2008. The complex carotenoid pattern of orange juices from concentrate. Food Chem 109 (3): 546-553. DOI: 10.1016/j.foodchem.2008.01.003.

Moran E, Ding L, Wang Z, Cheng R, Chen Q, Moore R, Takahashi Y, Ma JX. 2014. Protective and antioxidant effects of PPAR $\alpha$ the ischemic retina. Investig Ophthalmol Vis Sci 55 (7): 4568-4576. DOI: 10.1167/iovs.13-13127.

Mueller L, Boehm V. 2011. Antioxidant activity of $\beta$-carotene compounds in different in vitro assays. Molecules 16 (2): 1055-1069. DOI: 10.3390/molecules16021055.

Najihudin A, Chaerunisaa A, Subarnas A. 2017. Antioxidant activity of trengguli (Cassia Fistula L) bark extract and fraction using the DPPH method. Indon J Pharm Sci Technol 4 (2): 70-78. DOI: 10.15416/ijpst.v4i2.12354.

Ngginak J, Mangibulude JC, Rondonuwu FS. 2017. The identification of carotenoids and testing of carotenoid antioxidants from sand lobster (Panulirus homarus) egg extract. Ilmu Kelautan 22 (3): 155-160. DOI: 10.14710/ik.ijms.22.3.155-160. [Indonesian]

Oelkrug R, Goetze N, Meyer CW, Jastroch M. 2014. Antioxidant properties of UCP1 are evolutionarily conserved in mammals and buffer mitochondrial reactive oxygen species. Free Radic Biol Med 77: 210-216. DOI: 10.1016/j.freeradbiomed.2014.09.004

Oke JM, Hamburger O. 2002. Screening of some Nigerian medicinal plants for antioxidant activity using 2,2, diphenyl-picryl-hydrazyl radical. Afr J Biomed Res 5 (1-2): 77-79.

Paolini M, Abdel-Rahman SZ, Sapone A, Pedulli GF, Perocco P, CantelliForti G, Legator MS. 2003. $\beta$-carotene: a cancer chemopreventive agent or a co-carcinogen? Mut Res-Rev Mut Res 543 (3): 195-200. DOI: 10.1016/S1383-5742(03)00002-4.

Paransa DSJ, Kemer K, Rumengan AP, Mantiri DM. 2014. Pigment type analysis and antibacterial activity assay of xanthophyll pigment extract on brown algae Sargassum polycystum (C. Agardh). Jurnal LPPM Bidang Sains dan Teknologi 1 (1): 90-96. [Indonesian]

Pareek S, Sagar NA, Sharma S, Kumar V, Agarwal T, González-Aguilar GA, Yahia EM. 2017. Chlorophylls: chemistry and biological functions. In: Yahia EM (ed) Fruit and Vegetable Phytochemicals: Chemistry and Human Health: Second Edition (Vol. 1, $2^{\text {nd }}$ ed). John Wiley \& Sons Ltd, New Jersey. DOI: 10.1002/9781119158042.ch14.

Pérez-gálvez A, Viera I, Roca M. 2020. Carotenoids and chlorophylls as antioxidants. Antioxidants 9 (6): 1-39. DOI: 10.3390/antiox9060505.

Perreau F, Frey A, Effroy-Cuzzi D, Savane P, Berger A, Gissot L, Marion-Poll A. 2020. Abscisic acid-deficient4 has an essential function in both cis-violaxanthin and cis-neoxanthin synthesis. Plant Physiol 184 (3): 1303-1316. DOI: 10.1104/pp.20.00947.

Prabhu KH, Bhute AS. 2015. Plant based dyes and mordant: a review. J Nat Prod Plant Resour 2 (6): 649-664.

Pratiwi D, Wahdaningsih S, Isnindar. 2013. The test of antioxidant activity from bawang mekah leaves (Eleutherine americana Merr.) using DPPH (2,2-diphenyl-1-picrylhydrazyl) method. Trad Med J 18 (1): 9-16. DOI: 10.1007/s13398-014-0173-7.2.

Prestigiacomo V, Suter-Dick L. 2018. Nrf2 protects stellate cells from Smad-dependent cell activation. PLoS ONE 13 (7): 1-18. DOI: 10.1371/journal.pone.0201044.

Pringgenies D, Pratiwi AHD, Yudiati E, Azizah R, Susilo ES. 2017. Biopigment tracing of mangrove Rhizophora mucronata leaf and bark waste and its application in batik fabrics with various fixation methods. In: Dhramawan HA (eds.) Proceedings Book The 7th Basic 
Science International Conference. Universitas Brawijaya, Malang, 7-8 March 2017.

Pringgenies D, Ridlo A, Dewi LF, Djunaedi A. 2018. The commercial value of mangrove-based pigments as natural dye for batik textiles delianis. IntechOpen (Vol. 32). IntechOpen, London.

Puspitasar YE, Hartiati AM, Suprayitno E. 2012. The potency of Rhizophora mucronata leaf extract as antidiarrhea. J Appl Sci Res 8 (2): 1180-1185.

Radu GL, Litescu SC, Albu C, Teodor E, Truica G. 2012. Beta-carotene and lycopene determination in new enriched bakery products by HPLC-DAD method. Romanian Biotechnol Lett 17 (1): 7005-7012.

Ratnasari N, Walters M, Tsopmo A. 2017. Antioxidant and lipoxygenase activities of polyphenol extracts from oat brans treated with polysaccharide degrading enzymes. Heliyon 3 (7): e00351. DOI: 10.1016/j.heliyon.2017.e00351.

Ravikumar S, Gnanadesigan M. 2012. Hepatoprotective and antioxidant properties of Rhizophora mucronata mangrove plant in $\mathrm{CCl} 4$ intoxicated rats. J Exp Clin Med 4 (1): 66-72. DOI: 10.1016/j.jecm.2011.11.012

Ravindran C, Naveenan T, Varatharajan GR, Rajasabapathy R, Meena RM. 2012. Antioxidants in mangrove plants and endophytic fungal associations. Bot Mar 55 (3): 269-279. DOI: 10.1515/bot-2011-0095.

Revathi P, Jeyaseelan Senthinath T, Thirumalaikolundusubramanian P, Prabhu N. 2014. An overview of antidiabetic profile of mangrove plants. Int J Pharm Pharm Sci 6 (3): 1-5.

Ridlo A, Pramesti R, Koesoemadji K, Supriyantini E, Soenardjo N. 2017. Antioxidant activity of Rhizophora mucronata mangrove leaf extract. Buletin Oseanografi Marina 6 (2): 110-116. DOI: 10.14710/buloma.v6i2.16555. [Indonesian]

Riyadi PH, Romadhon, Anggo AD, Suharto S, Tanod WA, Aryani A. 2021. Anti-inflammatory potential from tilapia (Oreochromis niloticus) viscera hydrolysate with bioinformatics analysis (prediction of activity spectra for substances - PASS). IOP Conf Ser: Earth Environ Sci 750 (1): $012044 . \quad$ DOI: $10.1088 / 1755$ 1315/750/1/012044.

Riyadi PH, Tanod WA, Wahyudi D, Susanto E, Fahmi AS, Aisiah S. 2020. Potential of tilapia (Oreochromis niloticus) viscera bioactive peptides as antiviral for SARS-CoV-2 (COVID 19). IOP Conf Ser: Earth Environ Sci 584 (1): 012004. DOI: 10.1088/1755 $1315 / 584 / 1 / 012004$.

Riyadi PH, Wahyudi D, Tanod WA. 2019. Effects of dichloromethane Sarcophyton spp. extract on the lipopolysaccharide-induced expression of nuclear factor-kappa B and inducible nitric oxide synthase in mice. Vet World 12 (12): 1897-1902. DOI 10.14202/vetworld.2019.1897-1902.

Rohini RM, Das AK. 2009. A comparative evaluation of analgesic and anti-inflammatory activities of Rhizophora mucronata bark extracts. Pharmacologyonline 1: 780-791.

Rout P, Basak UC. 2014. Antioxidant properties in leaf and root extracts of some medicinally important mangrove species of Odisha coast. Am J Pharmtech Res 4: 605-617.

Ruban AV, Pascal AA, Robert B, Horton P. 2001. Configuration and dynamics of xanthophylls in light-harvesting antennae of higher plants. J Biol Chem 276 (27): 24862-24870. DOI: 10.1074/jbc.M103263200.

Rumengan AP, Mantiri DMH, Rompas R, Hutahaean A, Kepel TL, Paruntu CP, Kepel RC, Gerung GS. 2018. Carbon stock assessment of mangrove ecosystem in Totok bay, Southeast Minahasa regency, North Sulawesi, Indonesia. AACL Bioflux 11 (4): 1280-1288.

Şahin S, Aybastıer Ö, Dawbaa S, Karkar B, Çakmak T. 2020. Study of the ability of lutein and neoxanthin as standards and in the extract of Chlamydomonas reinhardtii to prevent oxidatively induced DNA base damage using ultrasensitive GC-MS/MS analysis. Chromatographia 83: 919-926. DOI: 10.1007/s10337-020-03918-8.

Saptiani G, Asikin AR, Ardhani F, Hardi EH. 2018. Mangrove plants species from Delta Mahakam, Indonesia with antimicrobial potency. Biodiversitas 19 (2): 516-521. DOI: 10.13057/biodiv/d190220.

Sarker U, Islam MT, Rabbani MG, Oba S. 2014. Genotypic variability for nutrient, antioxidant, yield and yield contributing traits in vegetable amaranth. J Food Agric Environ 12: 168-174.

Sarker U, Islam MT, Rabbani MG, Oba S. 2015a. Variability, heritability and genetic association in vegetable amaranth (Amaranthus tricolor L.). Spanish J Agric Res 13 (2): e0702. DOI: 10.5424/sjar/20151326843.
Sarker U, Islam T, Rabbani G, Oba S. 2015b. Genotype variability in composition of antioxidant vitamins and minerals in vegetable amaranth. Genetika 47 (1): 85-96. DOI: 10.2298/GENSR1501085S.

Sarker U, Islam MT, Rabbani MG, Oba S. 2017. Genotypic diversity in vegetable amaranth for antioxidant, nutrient and agronomic traits. Indian J Genet Plant Breed 77: 173-176. DOI: 10.5958/09756906.2017.00025.6.

Sarker U, Oba S. 2018a. Drought stress enhances nutritional and bioactive compounds, phenolic acids and antioxidant capacity of Amaranthus leafy vegetable. BMC Plant Biol 18 (1): 1-15. DOI:10.1186/s12870018-1484-1.

Sarker U, Oba S. 2018b. Catalase, superoxide dismutase and ascorbateglutathione cycle enzymes confer drought tolerance of Amaranthus tricolor. Sci Rep 8 (1): 1-12. DOI: 10.1038/s41598-018-34944-0.

Sarker U, Oba S. 2018c. Drought stress effects on growth, ros markers, compatible solutes, phenolics, flavonoids, and antioxidant activity in Amaranthus tricolor. Appl Biochem Biotechnol 186 (4): 999-1016. DOI: 10.1007/s12010-018-2784-5.

Sarker U, Oba S. 2018d. Augmentation of leaf color parameters, pigments, vitamins, phenolic acids, flavonoids and antioxidant activity in selected Amaranthus tricolor under salinity stress. Sci Rep 8 (1): 1-9. DOI: 10.1038/s41598-018-30897-6.

Sarker U, and Oba S. 2018e. Response of nutrients, minerals, antioxidant leaf pigments, vitamins, polyphenol, flavonoid and antioxidant activity in selected vegetable amaranth under four soil water content. Food Chem 252: 72-83. DOI: 10.1016/j.foodchem.2018.01.097.

Sarker U, Islam MT, Oba S. 2018a. Salinity stress accelerates nutrients, dietary fiber, minerals, phytochemicals and antioxidant activity in Amaranthus tricolor leaves. PLoS ONE 13 (11): e0206388. DOI: 10.1371/journal.pone.0206388.

Sarker U, Islam MT, Rabbani MG, Oba S. 2018b. Phenotypic divergence in vegetable amaranth for total antioxidant capacity, antioxidant profile, dietary fiber, nutritional and agronomic traits. Acta Agric Scand Sect B: Soil Plant Sci 68 (1): 67-76. DOI: 10.1080/09064710.2017.1367029.

Sarker U, Islam MT, Rabbani MG, Oba S. 2018c. Antioxidant leaf pigments and variability in vegetable amaranth. Genetika 50 (1): 209220. DOI: $10.2298 /$ GENSR1801209S.

Sarker U, Islam MT, Rabbani MG, Oba S. 2018d. Variability in total antioxidant capacity, antioxidant leaf pigments and foliage yield of vegetable amaranth. J Integrative Agric 17 (5): 1145-1153. DOI: 10.1016/S2095-3119(17)61778-7.

Sarker U, Oba S. 2019a. Antioxidant constituents of three selected red and green color Amaranthus leafy vegetable. Sci Rep 9 (1): 1-11. DOI: 10.1038/s41598-019-52033-8.

Sarker U, Oba S. 2019b. Nutraceuticals, antioxidant pigments, and phytochemicals in the leaves of Amaranthus spinosus and Amaranthus viridis weedy species. Sci Rep 9 (1): 1-10. DOI: $10.1038 / \mathrm{s} 41598-019-50977-5$

Sarker U, Oba S. 2019c. Protein, dietary fiber, minerals, antioxidant pigments and phytochemicals, and antioxidant activity in selected red morph Amaranthus leafy vegetable. PLoS ONE 14 (12): e0222517. DOI: 10.1371/journal. pone.0222517.

Sarker U, Oba S. 2019d. Salinity stress enhances color parameters, bioactive leaf pigments, vitamins, polyphenols, flavonoids and antioxidant activity in selected Amaranthus leafy vegetables. J Sci Food Agric 99 (5): 2275-2284. DOI: 10.1002/jsfa.9423.

Sarker U, Hossain MN, Iqbal MA, Oba S. 2020a. Bioactive components and radical scavenging activity in selected advance lines of salttolerant vegetable amaranth. Front Nutr 7: 1-15. DOI: $10.3389 /$ fnut.2020.587257.

Sarker U, Oba S, Daramy MA. 2020b. Nutrients, minerals, antioxidant pigments and phytochemicals, and antioxidant capacity of the leaves of stem amaranth. Sci Rep 10 (1): 1-9. DOI: 10.1038/s41598-02060252-7.

Sarker U, Hossain MM, Oba S. 2020c. Nutritional and antioxidant components and antioxidant capacity in green morph Amaranthus leafy vegetable. Sci Rep 10 (1): 1-10. DOI: 10.1038/s41598-02057687-3.

Sarker U, Oba S. 2020a. The response of salinity stress-induced $A$. tricolor to growth, anatomy, physiology, non-enzymatic and enzymatic antioxidants. Front Plant Sci 11: 1-14. DOI: $10.3389 /$ fpls.2020.559876.

Sarker U, Oba S. 2020b. Phenolic profiles and antioxidant activities in selected drought-tolerant leafy vegetable amaranth. Sci Rep 10 (1): 111. DOI: $10.1038 / \mathrm{s} 41598-020-71727-y$. 
Sarker U, Oba S. 2020c. Polyphenol and flavonoid profiles and radical scavenging activity in leafy vegetable Amaranthus gangeticus. BMC Plant Biol 20 (1): 1-12. DOI: 10.1186/s12870-020-02700-0.

Sarker U, Oba S. 2020d. Nutraceuticals, phytochemicals, and radical quenching ability of selected drought-tolerant advance lines of vegetable amaranth. BMC Plant Biol 20 (1): 1-16. DOI: 10.1186/s12870-020-02780-y.

Sarker U, Oba S. 2020e. Nutritional and bioactive constituents and scavenging capacity of radicals in Amaranthus hypochondriacus. Sci Rep 10 (1): 1-10. DOI: 10.1038/s41598-020-71714-3.

Sarker U, Oba S. 2020f. Nutrients, minerals, pigments, phytochemicals, and radical scavenging activity in Amaranthus blitum leafy vegetables. Sci Rep 10 (1): 1-9. DOI: 10.1038/s41598-020-59848-w.

Sarker U, Oba S. 2020g. Leaf pigmentation, its profiles and radica scavenging activity in selected Amaranthus tricolor leafy vegetables. Sci Rep 10 (1): 1-10. DOI: 10.1038/s41598-020-66376-0.

Sarker U, Oba S. 2021. Color attributes, betacyanin, and carotenoid profiles, bioactive components, and radical quenching capacity in selected Amaranthus gangeticus leafy vegetables. Sci Rep 11: 1-14. DOI: $10.1038 / \mathrm{s} 41598-021-91157-8$.

Sasamoto H, Hayatsu M, Suzuki S. 2020. High allelopathic activity of carotenoid-accumulating callus of a halophilic mangrove plant, Avicennia alba: protoplast co-culture method with digital image analysis. J Plant Stud 9 (1): 1-12. DOI: 10.5539/jps.v9n1p1.

Sasmito BB, Puspitasari YE, Hardoko H. 2016. Antidiabetic and antioxidant activities of tannin extract of Rhizophora mucronata leaves. J Chem Pharm Res 8 (3): 143-148.

Shabalina IG, Petrovic N, Kramarova TV, Hoeks J, Cannon B, Nedergaard J. 2006. UCP1 and defense against oxidative stress: 4 hydroxy-2-nonenal effects on brown fat mitochondria are uncoupling protein 1-independent. J Biol Chem 281 (20): 13882-13893. DOI: 10.1074/jbc.M601387200.

Soran H, Schofield JD, Durrington PN. 2015. Antioxidant properties of HDL. Front Pharmacol 6 (22): 1-6. DOI: 10.3389/fphar.2015.00222.

Strobel M, Tinz J, Biesalski HK. 2007. The importance of $\beta$-carotene as a source of vitamin A with special regard to pregnant and breastfeeding women. Eur J Nutr 46 (1): 1-20. DOI: 10.1007/s00394-007-1001-z.

Suganthy N, Pandima Devi K. 2016. In vitro antioxidant and anticholinesterase activities of Rhizophora mucronata. Pharma Biol 54 (1): 118-129. DOI: 10.3109/13880209.2015.1017886.

Taiz L, Zeiger E, Møller IM, Murphy A. 2006. Plant Physiology (Fifth). Sinauer Associates Inc., Massachusetts.

Tanod WA, Yanuhar U, Maftuch, Wahyudi D, Risjani Y. 2019a. DPPH scavenging property of bioactives from soft corals origin Palu bay,
Central Sulawesi, Indonesia. IOP Conf Ser: Earth Environ Sci 236 (1): 012121. DOI: 10.1088/1755-1315/236/1/012121.

Tanod WA, Dewanto DK, Ndobe S, Riyadi PH, Putra MY. 2019b. Screening of antibacterial and antioxidant activity of soft corals Sinularia sp. and Sarcophyton sp. from Palu bay, Central Sulawesi, Indonesia. Squalen: Bull Mar Fish Postharvest Biotechnol 14: 73-83. DOI: $10.15578 /$ squalen.v14i2.394.

Thatoi HN, Patra JK, Das SK. 2014. Free radical scavenging and antioxidant potential of mangrove plants: a review. Acta Physiol Plant 36 (3): 561-579. DOI: 10.1007/s1 1738-013-1438-z.

Tidore F, Rumengan AP, Sondak CFA, Mangindaan REP, Runtuwene HCC, Pratasik SB. 2018. Estimation of carbon (C) content in mangrove leaves from Lansa village, Wori sub-district, North Minahasa district. Jurnal Pesisir dan Laut Tropis 6 (2): 53-58. DOI: 10.35800/jplt.6.2.2018.21529. [Indonesian]

Wang F, Huang L, Gao B, Zhang C. 2018. Optimum production conditions, purification, identification, and antioxidant activity of violaxanthin from Microalga Eustigmatos cf. polyphem (Eustigmatophyceae). Mar Drugs 16 (6): 190-203. DOI: 10.3390/md16060190.

Widyowati H, Ulfah M, Sumantri. 2014. Antioxidant activity test of the herba alfalfa ethanolic extract (Medicago sativa L.) with the DPPH method (1,1-Diphenyl-2Picrylhidrazyl). Jurnal Ilmu Farmasi dan Farmasi Klinik 11: 25-33. [Indonesian]

Wu CL, Chen SD, Yin JH, Hwang CS, Yang DI. 2016. Nuclear factorkappaB-dependent sestrin2 induction mediates the antioxidant effects of BDNF against mitochondrial inhibition in rat cortical neurons. Mol Neurobiol 53 (6): 4126-4142. DOI: 10.1007/s12035-015-9357-1.

Wu CL, Yin JH, Hwang CS, Chen SD, Yang DY, Yang DI. 2012. C-Jundependent sulfiredoxin induction mediates BDNF protection against mitochondrial inhibition in rat cortical neurons. Neurobiol Dis 46 (2): 450-462. DOI: 10.1016/j.nbd.2012.02.010.

Yabluchanskiy A, Ma Y, Iyer RP, Hall ME, Lindsey ML. 2013. Matrix metalloproteinase-9: many shades of function in cardiovascular disease. Physiology 28 (6): 391-403. DOI: 10.1152/physiol.00029.2013.

Zapata M, Rodríguez F, Garrido JL. 2000. Separation of chlorophylls and carotenoids from marine phytoplankton: a new HPLC method using a reversed phase $\mathrm{C} 8$ column and pyridine-containing mobile phases. Mar Ecol Prog Ser 195: 29-45. DOI: 10.3354/meps195029.

Zhang T, Wang Z, Wang X, Sun W, Cui X, Li R, Li G. 2019. Effects of vitamin $\mathrm{A}$ on antioxidant functions, immune functions and production performance in male sika deer (Cervus nippon) during the first antler growth period. Ital J Anim Sci 18: 98-104. DOI: 10.1080/1828051X.2018.1456978. 